\title{
Carbon, nitrogen and phosphorus fluxes in four sub-tropical estuaries of northern KwaZulu-Natal: Case studies in the application of a mass balance approach
}

\author{
V Wepener \\ Department of Zoology, University of Johannesburg, PO Box 524, Auckland Park 2006, South Africa
}

\begin{abstract}
There are currently no South African nutrient standards for estuarine waters since the concentration of nutrients in the water column will not necessarily be predictive of the response by aquatic biota. In this paper a more suitable approach to assessing nutrients in relation to ecosystem integrity is proposed through compiling a nutrient mass balance for an estuary, which can identify major sources and sinks of nutrients. Recently there has been a move to develop budgets that link several variables using known stoichiometric relationships using limited data availability to infer underlying fluxes. The LOICZ biogeochemical budgeting protocol was applied to data from the Mhlathuze, Mvoti, Nhlabane and Thukela Estuaries in KwaZulu-Natal. Results indicated that these estuaries are all net sources of dissolved inorganic nitrogen and phosphates. The application of the flux-derived parameters used in the LOICZ modelling approach was used to demonstrate how nutrient assessment categories can be assigned to estuaries. As the LOICZ-derived fluxes represent steady-state conditions these were regarded as the reference/benchmark or present ecological state conditions. Alterations in the nutrient assessment category are demonstrated using hypothetical conditions in the Mhlathuze Estuary.
\end{abstract}

Keywords: KwaZulu-Natal estuaries, LOICZ biogeochemical model, nutrient fluxes, water quality category

\section{Introduction}

The chemistry of estuaries is dependent on a combination of tidal pulses, riverine flow, hydrodynamic and autochthonous biological processes (Allanson and Winter, 1999). The total concentrations (i.e. $\mu \mathrm{g} / \ell$ ) of nitrogen $(\mathrm{N})$ and phosphates $(\mathrm{P})$ in the water column are useful measures of the potential for eutrophication but they can often overestimate what is actually bioavailable for plant growth. Moreover, only measuring the concentration of nutrients in the water column does not take into account the fact that polluted water bodies will have significant stores of $\mathrm{N}$ and $\mathrm{P}$ in the sediments and associated with suspended particulate matter. Plants can derive their nutrients from sources other than in the water column, e.g. sea-grass beds meet their high nutrient demands by trapping nutrients and by uptake and recycling in the beds, not in the water column (Erftemeijer and Middleburg, 1995). Thus the concentration of nutrients in the water column will not necessarily be predictive of the response by aquatic biota. Grobbelaar (1992) argued that over-simplified models of nutrient loads are inadequate for estuaries and other ecosystems where hydrodynamic factors and high turbidity can mediate the effects of nutrients, as is the case in most South African estuaries.

It is for these reasons that there are currently no South African nutrient standards for estuarine waters. If available international standards (e.g. Australian) were adopted, then virtually all of South Africa's estuaries would be classified as eutrophic (Harrison et al., 2000). According to Harrison et al. (2000) the Australian standards reflect systems that are intrinsically different to those in South Africa, where fluvial effects naturally pro-

前 +27 11 489-3373; fax: +27 11 489-2286;

e-mail: victorw@uj.ac.za

Received 18 September 2006; accepted in revised form 1 March 2007. duce relatively higher nutrient concentrations. KwaZulu-Natal is a good example where nutrient concentrations, derived from detrital sources, result in relatively high background nutrient levels (Harrison et al., 2000). A more suitable approach to assessing nutrients in relation to ecosystem integrity would be through compiling a nutrient mass balance for an ecosystem, which can often help to identify major sources and sinks of nutrients. A mass balance represents all of the nutrients already present (i.e. water, sediments and biota) plus inputs, less the outputs (i.e. outflows and harvested biota like fish); what is left equals the internal load (Ekholm et al., 1997). Once the internal load is quantified, the external and internal processes which influence the load (e.g. biogeochemical cycling, primary production, etc.) can be identified. Information from the mass balance model will permit the locations where management actions can be targeted, which may include reduction of nutrient loads going into the system, preventing the release of nutrients from the sediments, or harvesting biota as a way to remove nutrients (ANZECC, 2000). This sort of approach is invariably more complicated than the traditional approach of dealing with issues such as nutrient pollution in isolation of other factors, but ecosystems are complex and if they are to be understood and managed sustainably a more sophisticated approach is required where whole ecosystem dynamics are taken into account (ANZECC, 2000).

This paper reports on the interpretation of chemical data from four sub-tropical estuaries in KwaZulu-Natal using the United Nations Environmental Program (UNEP) biogeochemical modelling framework. One of the central concerns of UNEPs 'International Geosphere-Biosphere Program: A Study of Global Change' (IGBP) is an improved understanding of the global carbon cycle and the likely changes which might occur as a consequence of global changes, both systemic and cumulative. 'The Land Ocean Interactions in the Coastal Zone (LOICZ) Core Project' of the IGBP, established in 1993, is concerned with 
understanding the role of the coastal sub-system in the functioning of the total earth system, including the role of the coastal zone in the disturbed and undisturbed cycles of carbon, nitrogen and phosphorus (Gordon et al., 1996). The key objectives of LOICZ are to:

- Gain a better understanding of the global cycles of the key elements carbon $(\mathrm{C})$, nitrogen $(\mathrm{N})$ and phosphorus $(\mathrm{P})$

- Understand how the coastal zone affects material fluxes through biogeochemical processes

- Characterise the relationship of these fluxes to environmental change, including human intervention (Pernetta and Milliman, 1995).

To achieve these objectives it was necessary to develop horizontal and, to a lesser extent, vertical material flux models. These models provide insight into flux dynamics from the continental basins through regional seas to continental oceanic margins, based on the understanding of biogeochemical processes and data for the coastal systems, habitats and human dimension (Dupra et al., 2002).

There are several advantages to developing simple models of fluxes, often thought of simply as nutrient budgets. They are both simple and comprehensive, so they give an overall picture of the system very quickly. In addition, their computation requires only the summation of the boundary fluxes of the system. A consequence of their simplicity is that limitations on the availability of data rapidly become evident. As a result, budget models provide both robust estimates of the flux across the coastal zone boundaries and long-term, integrated biogeochemical performance of the entire system. Furthermore, by treating the budget as a first step in the modelling procedure rather than as an end in itself, one can proceed to identify the major processes which determine the fluxes and make the important transition from a purely descriptive budget to a predictive process-based model. Recently there has been a move to develop budgets that link several variables using known relationships, for example building linked CNP budgets using stoichiometric relationships such as Redfield Ratios. The use of known stoichiometric relationships allows linked budgets to be applied in new areas, with limited data availability in order to infer underlying fluxes.

The objectives of this paper are twofold; firstly to apply the LOICZ biogeochemical budgeting protocol to data from the Mhlathuze, Mvoti, Nhlabane and Thukela Estuaries in KwaZulu-Natal. Secondly, an attempt is made at interpreting the results from the nutrient mass balance in a similar manner that physico-chemical parameters are described for freshwater systems within the EcoClassification framework (Kleynhans et al., 2005). The nutrient mass balance information obtained for the Mhlathuze Estuary is used as an example where a nutrient status category based on the degree of deviation from the reference condition is derived.

\section{Materials and methods}

The LOICZ approach is an ideal model for the South African situation where water quality data for most estuaries are extremely limited. The advantage of the LOICZ model is that extensive data sets are not required. This attribute makes the model robust and provides a widely applicable, uniform methodology to provide information on processes of CNP flux in estuaries. Within the context of LOICZ biogeochemical modelling, the primary question to be addressed concerns the role of the coastal zone as a source or sink for carbon, nitrogen, and phosphorus.

Conservation of mass is one of the most fundamental con-

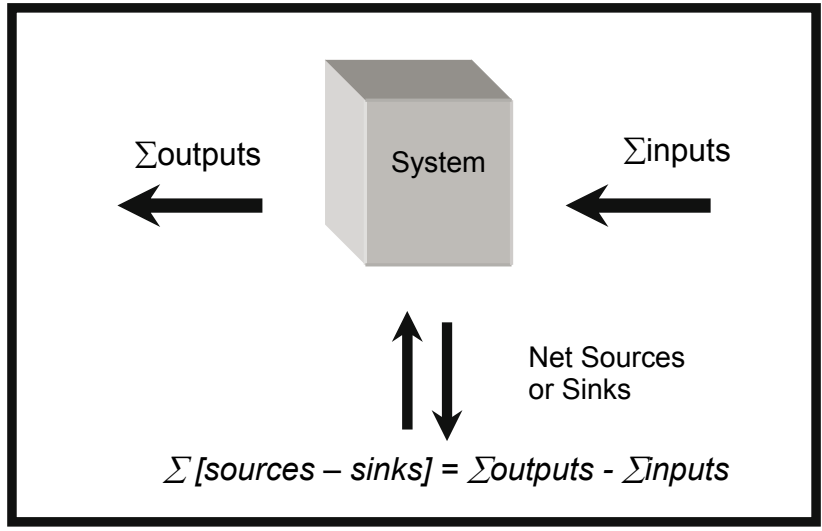

Figure 1

Generalised diagram indicating the components of the LOICZ budget procedure (adapted from Gordon et al., 1996)

cepts of ecology and geochemistry and the LOICZ budget procedure assumes that materials are conserved. The difference $(\Sigma$ [sources - sinks]) of imported ( $\Sigma$ inputs) and exported ( outputs) materials may be explained by the processes within the system (Fig. 1). For a detailed description on the mathematical structure of the LOICZ biogeochemical budgeting procedure the reader is referred to Gordon et al. (1996).

To build a budget model, it is necessary to define the spatial domain of the system to be modelled. The definition of the land boundary is usually relatively easy; it is likely to be defined by the shoreline or the limit of tidal excursion. However, in order to understand CNP processes in a system it is essential to provide background on the physical and biological characteristics of the particular system. Stoichiometrically linked water-saltnutrient budgets actually comprise a series of budgets, which are solved in a prescribed order. In general terms, the sequence of budgets for use in stoichiometrically linked CNP budgets follows four steps: water budgets, salt budgets, non-conservative materials and stoichiometric linkages among non-conservative budgets. The different methods and formulae used to derive the salt, water and nutrient budgets, as well as the stoichiometrical linkages were summarised from Gordon et al. (1996).

\section{Biophysical description of the estuaries}

To assess the water quality of a system it is essential to establish the extent of natural variation and the fate of substances entering the system. However, this is not possible unless the hydrodynamic characteristics of the estuary are understood (Taljaard and Slinger, 1997; Allanson, 2001). Essential biophysical information required includes system area and volume, river runoff, precipitation, evaporation, salinity gradient, nutrient loads (dissolved inorganic phosphorus (DIP), dissolved inorganic nitrogen (DIN), and if available, dissolved organic nitrogen (DON), dissolved organic phosphorus (DOP) and dissolved inorganic nitrogen (DIC)). A brief overview of the four estuaries assessed during this study is presented below. The positions of the estuaries along the north-east coast of South Africa are indicated in Fig. 2.

\section{Mhlathuze Estuary}

Based on Whitfield's classification for South African estuaries (Whitfield, 1992), the Mhlathuze Estuary $\left(28.80^{\circ} \mathrm{S}, 32.05^{\circ} \mathrm{E}\right)$ is situated in the subtropical coastal zone and could be regarded as a permanently open estuarine bay. The estuary covers an area of 
Figure 2 Diagram indicating the positions of the sampling sites in the selected estuaries for were calculated which nutrient budgets



during periods of high flows the estuary extends out to sea and becomes unconfined by banks (Begg, 1978).

km, and a total shoreline length of $30 \mathrm{~km}$ (Begg, 1978). This estuary contains significant mangrove stands which are dominated by the white mangrove (Avicennia marina) and to a lesser extent by the black mangrove (Bruguiera gymnorrhiza). Other emergent and submerged macrophytes that could play a role in the nutrient cycling in the estuary include extensive Phragmites australis and eelgrass (Zostera capensis) beds.

\section{Mvoti Estuary}

The abiotic and biotic characteristics of the Mvoti Estuary $\left(29.40^{\circ} \mathrm{S}, 31.35^{\circ} \mathrm{E}\right)$ are not comparable with any other estuary in KwaZulu-Natal (Begg, 1984). The system is best regarded as a river mouth with an extremely shallow mean depth $(<0.5$ $\mathrm{m}$; Mackay et al., 2000). The Mvoti catchment area is $2730 \mathrm{~km}^{2}$ and the $2 \mathrm{~km}^{2}$ estuary only makes up $0.2 \mathrm{~km}^{2}$ of the total catchment.

\section{Nhlabane Estuary}

Based on the classification by Whitfield (1992), the Nhlabane Estuary $\left(28.65^{\circ} \mathrm{S} ; 32.25^{\circ} \mathrm{E}\right)$ is situated in the subtropical coastal zone on the east coast of South Africa and is regarded as a temporarily open/closed estuary. The estuary is small, $3 \mathrm{~km}$ in length with a maximum width of $55 \mathrm{~m}$ in the lower reaches. Although it has a relatively pronounced basin with steep banks and associated riparian vegetation, it does meander through a small floodplain area (Vivier et al., 1998). The marginal, and at times emergent vegetation, is dominated almost exclusively by the common reed, $P$. australis.

\section{Thukela Estuary}

The Thukela Estuary is one of only two examples of an open river mouth estuarine system in South Africa (Whitfield, 1992). Due to high riverine runoff, the estuarine area of the Thukela is small. The surface area of the estuary during low flow periods is approximately $0.6 \mathrm{~km}^{2}$. However, changes in river flow result in considerable changes in the morphometry of the estuary, and

\section{Water budgets}

The concept of the hydrological cycle is well established, and is often presented (both globally and locally) in terms of water budgets. A simple diagram (Fig. 3A) represents this conceptual model. Freshwater inflows to a coastal marine system (such as runoff, precipitation and groundwater) and evaporation from the system are often rather easy to account for. The fundamental concept behind the budgets remains the conservation of water mass. Therefore, if it is assumed that either the water volume remains constant or that the change of water volume through time is known, then net water outflow from the system can be estimated by the difference. This flow is known as 'residual flow'; and although there are likely to be other flows, the difference between inflows and evaporative outflow must be balanced by this residual flow. As examples of judgment about individual systems, it is often (but not always) legitimate to assume that the system volume remains constant. Groundwater, sewage discharge, and other freshwater sources may often, but not always, be ignored. Often, but not always, runoff overwhelms the direct meteorological fluxes of precipitation and evaporation.

Since water is conserved, the water volume entering a system must equal water volume storage within the system minus the water volume flowing out of the system (Fig. 3A). Inflows include stream runoff $\left(\mathrm{V}_{\mathrm{Q}}\right)$, direct precipitation $\left(\mathrm{V}_{\mathrm{p}}\right)$, and groundwater $\left(\mathrm{V}_{\mathrm{G}}\right)$. There might be other inflows $\left(\mathrm{V}_{\mathrm{O}}\right)$ such as sewage. Removals include evaporation $\left(\mathrm{V}_{\mathrm{E}}\right)$. Whilst most coastal aquatic systems have inflows and outflows forced by winds and tides, the difference between inflows and outflows will tend towards zero when averaged over periods progressively longer than a single tidal cycle. The residual volume $\left(\mathrm{V}_{\mathrm{R}}\right)$ remains as the 'residual flow' required to balance the water budget (i.e. conserve volume). Note that $V_{R}$ is positive only in systems when evaporation exceeds precipitation and river inflow; that is, residual flow is into the system. In cases where freshwater input predominates, 
$\mathrm{V}_{\mathrm{R}}$ is negative.

Therefore, water storage may be represented by the change in system with time $\left(d V_{\text {sys }} / d t\right): d V_{\text {sys }} / d t=V_{Q}+V_{P}+V_{E}+V_{G}+V_{O}+V_{R}$ and at steady state flows equal or approximating zero can be eliminated to simplify the equation to:

$$
V_{R}=-\left(V_{Q}+V_{P}+V_{E}+V_{G}+V_{O}\right)
$$

\section{Salt budgets}

Coastal marine systems have flows across the system boundaries in addition to the residual flow. For example, these systems have water inflow and outflow associated with tides, winds, density, and large-scale circulation patterns. If the salinity of the system of interest as well as that of adjacent systems exchanging water with that system is known, then it may be possible to construct a salt budget (Fig. 3B), which includes these exchange flows in addition to residual flow. 'Salinity', as defined by oceanographers, could be regarded as the sum of all salts and is readily measured. Because salt is not being either produced or consumed in the system, salinity is said to be 'conservative' with respect to water within the system.

The primary equation representing the salt budget states that the salt flux is equal to each of the volume fluxes multiplied by the salinity (S) of each water type. In the case of the residually advecting water, the salinity is taken at the system boundary. The salinity of water in the system of interest (i.e. the estuary) is designated by $S_{S y s}$, whilst $S_{O c n}$ designates water outside the system. The salt flux not accounted for by the salinities used to describe the freshwater flow in the water budget must be balanced by mixing. The average salinity at the system boundary $\left(S_{R}\right)$ is calculated as $\left(S_{O c n}+S_{S y S}\right) / 2$. The salt flux carried by the residual flow could therefore be represented by $V_{R} S_{R}$. Since salt must be conserved the residual salt flux is brought back to the system through the mixing of salt flux across the boundary $\left(V_{X} S_{X}\right)$ via tides, wind and general circulation patterns. Therefore $V_{X} S_{X}=-V_{R} S_{R}$, with $S_{X}=\left(S_{O c n}-S_{S y s}\right)$. By rearrangement the mixing flux $\left(V_{X}\right)$ can be calculated as:

$$
V_{X}=-V_{R} S_{R} /\left(S_{O c n}-S_{S y S}\right)
$$

Total water exchange time is given by the ratio of the system volume to $\left(V_{R}+\left|V_{X}\right|\right)$. Note that in this derivation of circulation from combined water and salt budgets, there must be a salinity difference between $S_{O c n}$ and $S_{S y s}$.

\section{Budgets of non-conservative materials}

The next step in the budgeting exercise is to consider materials, which may not behave conservatively with respect to salinity (Fig. 3C). These budgets may be termed budgets of non-conservative materials. While this might be done with any reactive material (for example silica, which is actively involved in both biotic and abiotic reactions), of particular interest here is in the balance among the essential plant nutrient elements $\mathrm{C}, \mathrm{N}$, and $\mathrm{P}$. All dissolved elements will exchange between the system (estuary) and the adjacent ocean according to the criteria established in the water and salt budgets. Deviations are attributed to net non-conservative reactions of $\mathrm{N}$ and $\mathrm{P}$ in the system. This residual for each element is a measure of the net internal fluxes (that is, sources minus sinks) of these materials. The derivation of the equations used to calculate $\mathrm{N}$ and $\mathrm{P}$ fluxes in the systems is presented below. Since N and P are calculated similarly, they are
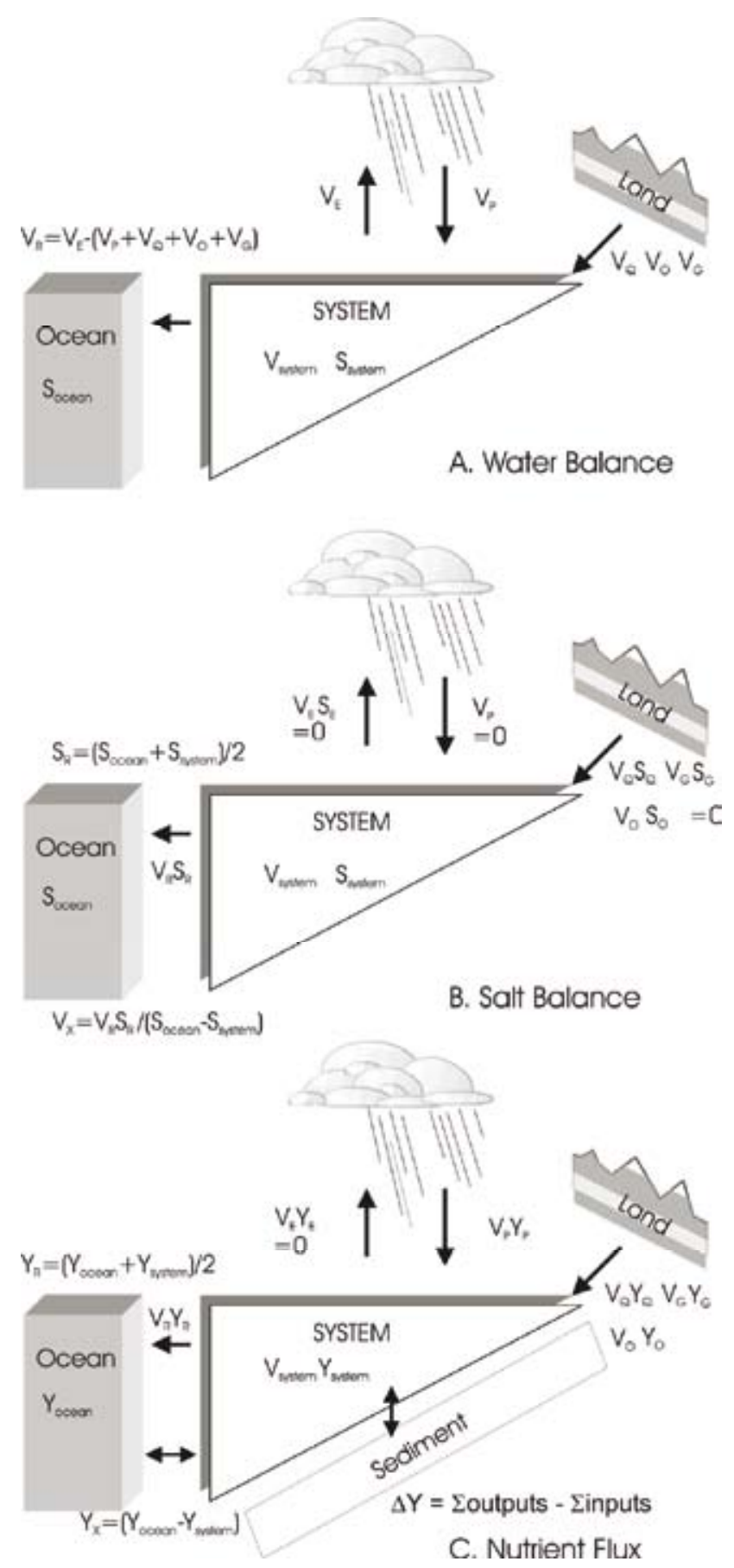

Figure 3

Generalised box diagrams illustrating the $A$ ) water budget, $B$ ) the salt budget and C) the budget for a non-conservative material, $Y$, in a coastal water bodies. (adapted from Gordon et al., 1996)

represented by $\Delta Y$ in the equations below. The residual nutrient fluxes $\left(Y_{R}\right)$ are calculated as $\left(Y_{O c n}+Y_{\text {Sys }}\right) / 2$. Thus: $d(V Y) / d t$ $=V_{Q} Y_{Q}+V_{G} Y_{G}+V_{O} Y_{O}+V_{P} Y_{P}+V_{E} Y_{E}+V_{R} Y_{R}+V_{X}\left(Y_{O c n}\right.$ $\left.-Y_{\text {syst }}\right)+\Delta Y$. Through eliminating the terms that are equal to or near 0 the equation can be rewritten as:

$$
\begin{aligned}
& 0=V_{Q} Y_{Q}+V_{G} Y_{G}+V_{O} Y_{O}+V_{R} Y_{R}+V_{X}\left(Y_{\text {ocn }}-Y_{\text {syst }}\right)+\Delta Y \\
& \Delta Y=-V_{Q} Y_{Q}-V_{G} Y_{G}-V_{O} Y_{O}-V_{R} Y_{R}-V_{X}\left(Y_{\text {ocn }}-Y_{\text {syst }}\right)
\end{aligned}
$$




\section{Stoichiometric linkages among non-conservative budgets}

The next step involves developing the stoichiometric linkages among non-conservative budgets. According to Gordon et al. (1996) the basic assumptions for the LOICZ model are that net biogeochemical processes in coastal marine systems are dominated by a few specific chemical reactions; that the biogeochemical cycles of $\mathrm{C}, \mathrm{N}$, and $\mathrm{P}$ are intimately linked; and that the approximate stoichiometric relationships among these elements for the dominating reactions can be written. Much of the flux of $\mathrm{C}, \mathrm{N}$, and $\mathrm{P}$ in coastal waters is attributed to production and consumption of organic matter, and the composition of organic matter tends to be relatively constant within the ocean. If plankton metabolism dominates, then the well-established 'Redfield Ratio' (Redfield, 1934) is likely to be a reasonable approximation of the C: N: P ratio of locally produced (or consumed) organic matter. If the system metabolism is dominated by sea-grass or benthic algal metabolism, then some other composition may be more appropriate (Atkinson and Smith, 1983). For systems in which sedimentary materials apparently dominate the local reaction, or in which particle inputs and outputs can be assumed to be small, then the sediment composition may be an appropriate compositional ratio to consider. In any case, some estimate can be made of the local organic matter composition (Gordon et al., 1996).

For the sake of linking the $\mathrm{C}, \mathrm{N}$, and $\mathrm{P}$ budgets, $\mathrm{P}$ may be considered to have the simplest chemical pathways. All $\mathrm{P}$ in the system can be considered to be in either the dissolved or the particulate phase, and $\mathrm{P}$ reactions involve transfers between these phases; there is no gas phase. In contrast, both $\mathrm{N}$ and $\mathrm{C}$ have prominent gas phases, and $\mathrm{C}$ and $\mathrm{N}$ fluxes involving the gas phases are known to be important in coastal systems. The working assumption is therefore made that the internal reaction flux of $\mathrm{P}$ is proportional to production and consumption of particulate material (generally dominated by organic matter). That is, phosphorus moves back and forth between dissolved and particulate material. $\mathrm{N}: \mathrm{P}$ and $\mathrm{C}: \mathrm{P}$ flux ratios are calculated from the budgetary analyses, and deviations of these flux ratios from proportionality with respect to the particle composition are attributed to gas-phase reactions for nitrogen and carbon (Gordon et al., 1996). According to these authors the $\mathrm{N}_{2}$ content of seawater may for all practical purposes be considered to be controlled by gas solubility and equilibration of $\mathrm{N}_{2}$ partial pressure between seawater and the overlying atmosphere. Therefore this stoichiometric procedure is a relatively robust way to estimate the difference between nitrogen fixation and denitrification.

Thus for the purposes of calculating water exchange in the coastal system, water and salt budgets are used. The departure of nutrient budgets from conservative flux behaviour provides the measure 'system biogeochemical fluxes.' The non-conservative dissolved inorganic phosphate (DIP) flux is assumed proportional to the difference between photosynthesis (p) and respiration (r). Thus by using the 'Redfield Ratio', i.e. C: N: P =106: $16: 1$, the net ecosystem metabolism (primary production - respiration) can be calculated as $(\mathrm{p}-\mathrm{r})=-\Delta \mathrm{DIP}(\mathrm{C}$ : P) using the Redfield Ratio. Mismatch from 'Redfield expectations' for DIP and dissolved inorganic nitrogen (DIN) flux is assumed proportional to the difference between nitrogen fixation and denitrification. The observed nitrogen flux $(\Delta \mathrm{DIN})$ represents the product of fixation whereas the denitrification product (expected $\mathrm{DIN}$ ) is regarded as $\triangle \mathrm{DIP}(\mathrm{N}: \mathrm{P})$ using the Redfield Ratio.

\section{Results and discussion}

\section{Water and salt balances}

The assumption required to apply the steady-state water balance equation to a system is that the water volume is steady over time. All the estuaries in this study undergo marked water volume changes due to a variety of factors. Thus the LOICZ modelling assumption is not valid over short (i.e. daily) time frames and it is thus necessary to average the water balance equation over an extended period of time, which results in a constant estimation of water volume. Due to the fragmented and limited data available it was only possible to construct one-box flux models for the four estuaries under investigation. This does not imply that there is no salinity stratification present.

The Mhlathuze Estuary undergoes marked water volume changes due to tidal action through the permanently open mouth. For LOICZ biogeochemical modelling, it is important to estimate the mixing volume $\left(V_{X}\right.$ in $\left.\mathrm{m}^{3} \cdot \mathrm{d}^{-1}\right)$ across the open boundary of the system. The basis for calculating the flux is the presence of a measurable difference in salinity between the estuary and the coastal sea. However, since there is a limited difference between the Mhlathuze Estuary and the ocean and for the Mhlathuze system, an alternative procedure to calculating the $V_{X}$ is also included. That procedure (Yanagi, 2000a) makes use of the dispersion process where the magnitude of the horizontal dispersion coefficient $\left(D_{h}\right.$ in $\left.\mathrm{m}^{2} \cdot \mathrm{d}^{-1}\right)$ is estimated from the current shear and the diffusivity normal to current shear. According to Dodd (1994) current shear can be regarded as the bottom shear stress affecting both the out-flowing freshwater (which it opposes) and the onset (or otherwise) of a shear instability in the out-flowing current through its aforementioned effect on the mean current. For wide and shallow estuaries the following equation is used:

$$
D_{h}=W^{0.85} U^{2} / 2180
$$

where:

$W$ denotes the width of the estuary mouth in $\mathrm{m}$

$U$ is the residual flow velocity at the surface layer of the open boundary in $\mathrm{m} \cdot \mathrm{d}^{-1}$

Since $U$ is not independently known, a numerical value of 8640 $\mathrm{m} \cdot \mathrm{d}^{-1}$ was applied (Yanagi, 2000a). In order to express $D_{h}$ in LOICZ notation, the following equation was used for calculating $V_{X}$ (Yanagi, 2000b):

$$
V_{X}=D_{h}(A / F)
$$

where:

A denotes the cross-sectional area of the open boundary of the system $\left(\mathrm{m}^{2}\right)$

$F$ is the distance (m) between the geographic centre of the system and the observation point for oceanic salinity (typically near the mouth of the system)

The following results for $D_{h}$ and $V_{X}$ were calculated for the Mhlathuze Estuary using Eqs. (4) and (5):

$D_{h}=\left(200^{0.85}(0.1 * 86.400)^{2}\right) / 2180$

$D_{h}=3.10010^{3} \mathrm{~m}^{3} \cdot \mathrm{d}^{-1}$

$V_{X}=D_{h}(\mathrm{~A} / F)$

$V_{X}=3.100 \times 10^{3} \mathrm{~m}^{2} \cdot \mathrm{d}^{-1}\left(5.000 \mathrm{~m}^{2} / 3.000 \mathrm{~m}\right)$

$V_{X}=5.200 \times 10^{3} \mathrm{~m}^{3} \cdot \mathrm{d}^{-1}$ 


\begin{tabular}{|c|c|c|c|c|}
\hline \multicolumn{5}{|c|}{$\begin{array}{c}\text { TABLE } 1 \\
\text { Water fluxes, salinity and nutrient concentrations, and data sources for the Mhlathuze and Mvoti Estuaries }\end{array}$} \\
\hline \multirow[t]{2}{*}{ Quantity } & \multicolumn{2}{|r|}{ Mhlathuze Estuary } & \multicolumn{2}{|r|}{ Mvoti Estuary } \\
\hline & Value & Data source & Value & Data source \\
\hline $\begin{array}{l}V_{Q} \\
\left(10^{3} \cdot m^{3} \cdot d^{-1}\right)\end{array}$ & 438 & $\begin{array}{l}\text { Average annual flow as measured at DWAF weir } \\
\text { W1H032 for the period 1995-1998 (Cyrus et al., } \\
\text { 2000). }\end{array}$ & 236 & $\begin{array}{l}\text { Runoff measured at gauging weir in the } \\
\text { Mvoti River at (Fig. 2) during August } 2000 \\
\text { (Mackay et al., 2000) }\end{array}$ \\
\hline $\begin{array}{l}V_{\mathrm{p}} \\
\left(10^{3} \cdot \mathrm{m}^{3} \cdot \mathrm{d}^{-1}\right)\end{array}$ & 39 & $\begin{array}{l}\text { Average yearly rainfall from the South African } \\
\text { Weather Bureau as supplied by the Comput- } \\
\text { ing Center for Water Research (CCWR) for the } \\
\text { Mhlathuze catchment. }\end{array}$ & 0.5 & $\begin{array}{l}\text { Mean annual precipitation in Mvoti catch- } \\
\text { ment (Mvoti IFR Starter Document, 1996) }\end{array}$ \\
\hline $\begin{array}{l}V_{E} \\
\left(10^{3} \cdot m^{3} \cdot d^{-1}\right)\end{array}$ & -42 & $\begin{array}{l}\text { Average yearly evaporation rates from the South } \\
\text { African Weather Bureau as supplied by the } \\
\text { Computing Center for Water Research (CCWR) } \\
\text { for the Mhlathuze catchment. }\end{array}$ & -0.8 & $\begin{array}{l}\text { Mean annual evaporation in Mvoti catch- } \\
\text { ment (Mvoti IFR Starter Document, 1996) }\end{array}$ \\
\hline $\begin{array}{l}V_{G} \\
\left(10^{3} \cdot m^{3} \cdot d^{-1}\right)\end{array}$ & 12 & $\begin{array}{l}\text { Ground water recharge calculated for the } \\
\text { Mhlathuze coastal plain as approximately } 30 \% \text { of } \\
\text { the mean annual precipitation (Louw, 1998). }\end{array}$ & 0.05 & $\begin{array}{l}\text { Ground water recharge for the Mvoti } \\
\text { Estuary subcatcment calculated as } 30 \% \\
\text { of MAR in estuarine catchment. (Prof. B. } \\
\text { Kelbe pers. com., Department of Hydrol- } \\
\text { ogy, University of Zululand) }\end{array}$ \\
\hline $\mathrm{S}_{\text {ocn }}(\%)$ & 35.4 & CSIR off-shore sampling. & 35.4 & $\begin{array}{l}\text { CSIR off-shore sampling - KwaZulu Natal } \\
\text { coast }\end{array}$ \\
\hline $\mathrm{S}_{\text {syst }}(\% o)$ & 34.5 & $\begin{array}{l}\text { Average salinity at all sites sampled at the } \\
\text { surface when the mouth is open. Quarterly data } \\
\text { from March } 1996 \text { to April 1998. This represents } \\
\text { the average salinity of the outflowing surface } \\
\text { layer (Cyrus et al., 2000). }\end{array}$ & 0.5 & $\begin{array}{l}\text { The average salinity of sites measured in } \\
\text { the Mvoti Estuary during August } 2000 \\
\text { (Mackay et al., 2000). }\end{array}$ \\
\hline $\begin{array}{l}\mathrm{DIP}_{\mathrm{Q}}, \mathrm{DIN}_{\mathrm{Q}} \\
(\Delta \mu \mathrm{M})\end{array}$ & $0.7,25$ & $\begin{array}{l}\text { Monthly averages of sites sampled in the lower } \\
\text { reaches of the Mhlathuze River from 1996-1998 } \\
\text { (Cyrus et al., 2000). }\end{array}$ & $4.5,44$ & $\begin{array}{l}\text { Six-week average of nutrients measured at } \\
\text { the gauging weir in the Mvoti River during } \\
\text { August } 2000 \text { (Mackay et al., 2000). }\end{array}$ \\
\hline $\begin{array}{l}\mathrm{DIP}_{G}, \mathrm{DIN}_{\mathrm{G}} \\
(\Delta \mu \mathrm{M})\end{array}$ & $1.0,14$ & $\begin{array}{l}\text { Bore-hole monitoring results from the Mhlathuze } \\
\text { floodplain for the period 1986-2000 (Clean } \\
\text { Stream, 2000). }\end{array}$ & $7.1,37$ & $\begin{array}{l}\text { Six-week average of nutrients measured at } \\
\text { sampling sites in the Mvoti Estuary during } \\
\text { August } 2000 \text { (Mackay et al., 2000). }\end{array}$ \\
\hline $\begin{array}{l}\text { DIP }_{\text {syst }} \\
\text { DIN }_{\text {syst }} \\
(\Delta \mu M)\end{array}$ & $5.8,14$ & $\begin{array}{l}\text { Averages of sites sampled in the Mhlathuze Estu- } \\
\text { ary (Cyrus et al.., 2000). }\end{array}$ & $0.3,0.8$ & $\begin{array}{l}\text { Since the mouth of the estuary was never } \\
\text { completely flushed with fresh seawater it } \\
\text { was necessary to use average nutrient data } \\
\text { for the east coast of South Africa as con- } \\
\text { tained in the Levitus } 94 \text { dataset of the Lan- } \\
\text { man-Doherty Environmental Observatory. }\end{array}$ \\
\hline $\begin{array}{l}\mathrm{DIP}_{\text {ocn }} \\
\mathrm{DIN}_{\text {ocn }} \\
(\Delta \mu \mathrm{M})\end{array}$ & $0.1,0.7$ & $\begin{array}{l}\text { Readings at the mouth of the estuary when com- } \\
\text { pletely flushed with fresh seawater (Wepener and } \\
\text { Vermeulen, 1999). }\end{array}$ & $1.3,2$ & $\begin{array}{l}\text { Readings at the mouth of the estuary when } \\
\text { completely flushed with fresh seawater. }\end{array}$ \\
\hline
\end{tabular}

Figure 4A shows the water and salt balance for the Mhlathuze Estuary with annual averages using the two equations given above. $V_{X}{ }^{a}$ is volume mixing calculated using the LOICZ water and salt balance and $V_{X}{ }^{b}$ is calculated using the dispersion coefficient. For the purposes of this paper, the conservative estimate for total water exchange time $(\tau)$ calculated using $V_{X}^{b}$ was used, i.e. 4 d. The relatively rapid exchange period is attributed to the large tidal height of $1.8 \mathrm{~m}$ in this shallow estuary (average depth at high tide of $2 \mathrm{~m}$ ). The system is therefore dominated by tidal mixing due to the inflow of marine water in the greatest proportion of the estuary (i.e. the embayment area). Although there is significant freshwater inflow via the canalised portion of the river, mixing of marine water and freshwater only occurs during high tide. During low tide the marine water (estuarine brackish water) is replaced by freshwater flow from the river. The freshwater is mainly restricted to the canalised area, with the embayment remaining marine dominated. Table 1 presents the water fluxes, salinity and nutrient concen- trations, and data sources for the Mhlathuze Estuary used in this budget assessment.

Water fluxes, salinity and nutrient concentrations, and data sources for Mvoti Estuary used in this budget assessment are presented in Table 1. All values presented are based on the average of six weekly samples taken during August/September 2000. Figure $5 \mathrm{~A}$ illustrates the water and salt balance for the Mvoti Estuary with six-weekly averages using the LOICZ methodology. Residual water flux $\left(V_{R}\right.$ in the notation of Gordon et al., 1996) from this system, to balance freshwater inflow, is approximately $236 \times 10^{3} \mathrm{~m}^{3} \cdot \mathrm{d}^{-1}$, while exchange flux $\left(V_{X}\right)$ is $121 \times 10^{3} \mathrm{~m}^{3} \cdot \mathrm{d}^{-1}$. The system volume $\left(125 \times 10^{3} \mathrm{~m}^{3}\right)$ divided by the sum of these water fluxes gives an estimate of water exchange time of less than a day. These results indicate an extremely rapid seawater exchange within the estuary, which is caused by the significant freshwater outflow through the mouth. The morphology of the Mvoti Estuary constitutes a relatively narrow riverine channel and does not allow for the development of any backwater 

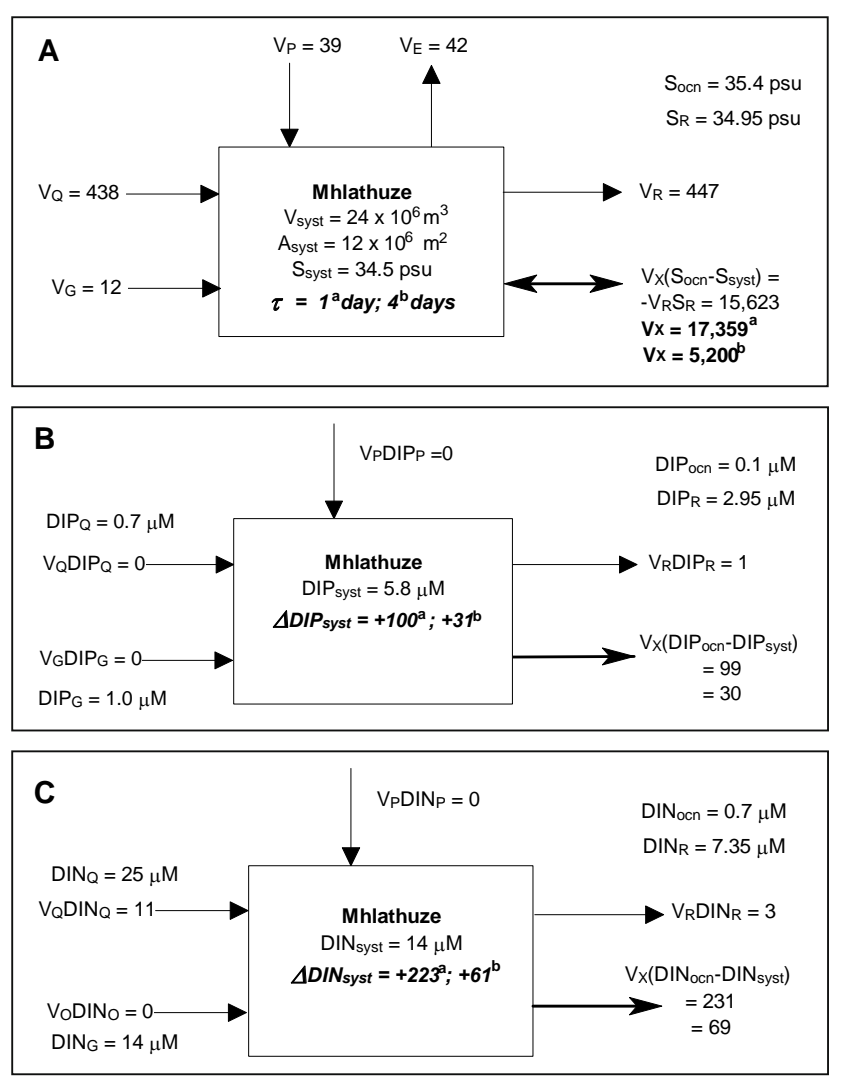

Figure 4

Water and salt budgets $(A)$, dissolved inorganic phosphorous budget $(B)$ and dissolved inorganic nitrogen budget $(C)$ for the Mhlathuze Estuary. Water flux is presented in $10^{6} \cdot \mathrm{m}^{3} \cdot \mathrm{d}^{-1}$ and salt flux in $10^{6} \cdot \mathrm{psu}-\mathrm{m}^{3} \cdot \mathrm{d}^{-1}$, whereas nutrient fluxes are in $10^{3} \cdot \mathrm{m}^{3} \cdot \mathrm{d}^{-1}$.

(lagoon) area that could contribute towards a longer retention time.

Nhlabane Estuary also undergoes marked water volume changes due to the periodical opening and closing of the mouth. Water fluxes, salinity and nutrient concentrations, and data sources for Nhlabane Estuary used in this budget assessment are presented in Table 2. Figure 6A illustrates the water and salt balance for the Nhlabane Estuary with annual averages using the LOICZ methodology. Residual water flux $\left(V_{R}\right)$ from this system, to balance freshwater inflow, is approximately $21 \times 10^{3} \mathrm{~m}^{3} \cdot \mathrm{d}^{-1}$, while the exchange flux $\left(V_{X}\right)$ is $17 \times 10^{3} \mathrm{~m}^{3} \cdot \mathrm{d}^{-1}$. The system volume $\left(200 \times 10^{3} \mathrm{~m}^{3}\right)$ divided by the sum of these water fluxes gives an estimate of water exchange time of approximately $5 \mathrm{~d}$. During the study period the opening of the mouth was primarily driven by groundwater inputs from the surrounding dunes since no (or very little) freshwater input from the lake took place. Based on personal observations the estuary would drain very rapidly during low tide once the sandbar is breached. Normal tidal exchange would take place in the estuary for 5 to $7 \mathrm{~d}$ before wave action closes the mouth of the estuary again. Continuous groundwater inputs then fill the estuary over a period of approximately $7 \mathrm{~d}$ resulting in the breaching of the sand bar again. It must be borne in mind that the data presented here were recorded during an extreme drought period and it is possible that in subsequent years additional freshwater input from the lake can be expected as freshwater flows over the barrage. However, there is no gauging facility on the barrage


Figure 5

Water and salt budgets $(A)$, dissolved inorganic phosphorous budget $(B)$ and dissolved inorganic nitrogen budget $(C)$ for the Mvoti Estuary. Water flux is presented in $10^{6} \cdot \mathrm{m}^{3} \cdot d^{-1}$ and salt flux in $10^{6} \cdot \mathrm{psu}-\mathrm{m}^{3} \cdot \mathrm{d}^{-1}$, whereas nutrient fluxes are in $10^{3} \cdot \mathrm{m}^{3} \cdot \mathrm{d}^{-1}$.

structure so that no quantitative assessment of freshwater input can be expected. Therefore this budget represents the conditions experienced during low-flow periods in the Nhlabane Estuary.

The water balance equation for the Thukela Estuary was once again calculated based on the LOICZ assumption that either water volume remains constant or that the change of water volume through time is known, then net water outflow from the system can be estimated by difference (Gordon et al., 1996). Water fluxes, salinity and nutrient concentrations, and data sources for Thukela Estuary used in this budgetary assessment are presented in Table 7. Figure 7A illustrates the water and salt balance for the Thukela Estuary with annual averages using the LOICZ methodology. Residual water flux from this system, to balance freshwater inflow, is approximately $3 \times 10^{6} \mathrm{~m}^{3} \cdot \mathrm{d}^{-1}$, while exchange flux $\left(V_{X}\right)$ is $2 \times 10^{6} \mathrm{~m}^{3} \cdot \mathrm{d}^{-1}$. The system volume $\left(0.9 \times 10^{6} \mathrm{~m}^{3}\right)$ divided by the sum of these water fluxes gives an estimate of water exchange time of less than a day. These results indicate an extremely rapid seawater exchange within the estuary, which is caused by the significant freshwater outflow. It is this abundant freshwater supply from the Thukela River, which has led to the large inter-basin (Davies and Snaddon, 2000) water transfer schemes currently in place and planned for the future. 


\begin{tabular}{|c|c|c|c|c|}
\hline \multicolumn{5}{|c|}{$\begin{array}{cc}\text { TABLE } 2 \\
\text { Water fluxes, salinity and nutrient concentration }\end{array}$} \\
\hline \multirow[b]{2}{*}{ Quantity } & \multicolumn{2}{|c|}{ Nhlabane Estuary } & \multicolumn{2}{|c|}{ Thukela Estuary } \\
\hline & \begin{tabular}{|l|} 
Value \\
\end{tabular} & Data source & Value & Data source \\
\hline $\begin{array}{l}\mathrm{V}_{\mathrm{Q}} \\
\left(10^{3} \cdot \mathrm{m}^{3} \cdot \mathrm{d}^{-1}\right)\end{array}$ & 192 & $\begin{array}{l}\text { Average annual runoff in Nhlabane } \\
\text { catchment (Quinn, 1999) but was not } \\
\text { used in the budget calculation due to no } \\
\text { water entering the estuary from the lake } \\
\text { during the study period. }\end{array}$ & 3,014 & $\begin{array}{l}\text { Average annual flow as measured at DWAF } \\
\text { weir V5H002 for the period 1970-1996 as } \\
\text { reported by Archibald (1998a). }\end{array}$ \\
\hline $\begin{array}{l}\mathrm{V}_{\mathrm{P}} \\
\left(10^{3} \cdot \mathrm{m}^{3} \cdot \mathrm{d}^{-1}\right)\end{array}$ & 0.5 & $\begin{array}{l}\text { Average yearly rainfall in the Nhlabane } \\
\text { catchment - Source R. Hattingh (Envi- } \\
\text { ronmental Scientist, RBM). }\end{array}$ & 1.64 & $\begin{array}{l}\text { Average yearly rainfall from the South Afri- } \\
\text { can Weather Bureau as supplied by the Com- } \\
\text { puting Center for Water Research (CCWR) } \\
\text { for the Thukela catchment. }\end{array}$ \\
\hline $\begin{array}{l}\mathrm{V}_{\mathrm{E}} \\
\left(10^{3} \cdot \mathrm{m}^{3} \cdot \mathrm{d}^{-1}\right)\end{array}$ & -0.4 & $\begin{array}{l}\text { Average yearly evaporation rates from } \\
\text { the South African Weather Bureau as } \\
\text { supplied by the Computing Center for } \\
\text { Water Research (CCWR) for the Rich- } \\
\text { ards Bay coastal plain area. } \\
\end{array}$ & -2.14 & $\begin{array}{l}\text { Average yearly evaporation rates from the } \\
\text { South African Weather Bureau as supplied } \\
\text { by the Computing Center for Water Research } \\
\text { (CCWR) for the Thukela catchment. }\end{array}$ \\
\hline $\begin{array}{l}\mathrm{V}_{\mathrm{G}} \\
\left(10^{3} \cdot \mathrm{m}^{3} \cdot \mathrm{d}^{-1}\right)\end{array}$ & 21 & $\begin{array}{l}\text { Ground water recharge calculated for } \\
\text { the Nhlabane system (Quinn, 1999). }\end{array}$ & 0.08 & $\begin{array}{l}\text { Ground water recharge calculated for the } \\
\text { Thukela catchment as approximately } 5 \% \text { of } \\
\text { the mean annual precipitation. }\end{array}$ \\
\hline $\mathrm{S}_{\text {ocn }}(\%)$ & 35.4 & CSIR off-shore sampling & 35.4 & CSIR off-shore sampling. \\
\hline $\mathrm{S}_{\text {syst }}(\%)$ & 8.8 & $\begin{array}{l}\text { This represents the average salinity of } \\
\text { the outflowing surface layer measured at } \\
\text { all the sampling sites between } 1993 \text { and } \\
1996 \text { (Vivier et al., 1998). }\end{array}$ & 2.2 & $\begin{array}{l}\text { Average surface salinity at the site in the } \\
\text { mouth of the open mouth of the estuary. } \\
\text { Monthly data from April } 1997 \text { to March } 1998 . \\
\text { This represents the average salinity of the } \\
\text { outflowing surface layer. }\end{array}$ \\
\hline $\begin{array}{l}\mathrm{DIP}_{Q}, \mathrm{DIN}_{\mathrm{Q}} \\
(\Delta \mu \mathrm{M})\end{array}$ & $2.1,28$ & $\begin{array}{l}\text { Nutrient concentrations measured in } \\
\text { borehole samples from Lake Nhlabane } \\
\text { catchment - Source R. Hattingh (Envi- } \\
\text { ronmental Scientist, RBM). }\end{array}$ & $0.9,27$ & $\begin{array}{l}\text { Average biweekly water quality data (1994- } \\
\text { 1998) from lowest most gauging weir in } \\
\text { the Thukela River (DWAF Weir V5H002) } \\
\text { (Archibald, 1998a) }\end{array}$ \\
\hline $\begin{array}{l}\mathrm{DIP}_{\text {syst}}, \mathrm{DIN}_{\text {syst }} \\
(\Delta \mu \mathrm{M})\end{array}$ & $4.5,84$ & $\begin{array}{l}\text { Average of sites in Nhlabane Estuary } \\
\text { monitored during 1993-1996 (Kemper, } \\
\text { 1999). }\end{array}$ & & $\begin{array}{l}\text { Average nutrient data for the east coast of } \\
\text { South Africa as contained in the Levitus } 94 \\
\text { dataset of the Lanman-Doherty Environmen- } \\
\text { tal Observatory. }\end{array}$ \\
\hline $\begin{array}{l}\mathrm{DIP}_{\text {ocn }}, \mathrm{DIN}_{\text {ocn }} \\
(\Delta \mu \mathrm{M})\end{array}$ & $0.7,2$ & $\begin{array}{l}\text { Readings at the site closest to the open } \\
\text { mouth of the estuary when completely } \\
\text { flushed with fresh seawater. }\end{array}$ & $5.5,137$ & $\begin{array}{l}\text { CRUZ monthly data from April 1997-March } \\
1998 \text { collected from sites in the estuary and } \\
\text { reported by Archibald (1998a) }\end{array}$ \\
\hline
\end{tabular}

\section{Non-conservative DIN and DIP budgets}

Assuming a steady state for both DIN and DIP over the entire sampling period, and that the nutrient concentration in evaporated water and the nutrient contribution from groundwater and rainwater are negligible, the nutrient budget equation can be simplified to $\Delta Y=-V_{R} Y_{R}-V_{G} Y_{G}-V_{Q} Y_{Q}-V_{X}\left(Y_{\text {ocn }}-Y_{\text {sys }}\right)$. It is known that the nearby coastal lakes in the Mhlathuze catchment are affected by significant aerial deposition of nitrogenous and phosphorus compounds from an adjacent fertiliser industry (Archibald, 1998b). However the prevailing wind conditions are such that direct deposition in the estuary or even in the lower catchment of the Mhlathuze River is unlikely. Nutrient budgets are illustrated in Figs. 4B and C. Non-conservative fluxes with superscript $\left({ }^{a}\right)$ and $\left(^{b}\right)$ were derived using $V_{X}^{a}$ and $V_{X}^{b}$, as indicated in the previous section respectively.

For the purposes of calculating nutrient balances and system metabolism the results based on the most conservative of the flux calculations were used (i.e. fluxes based on current shear). The Mhlathuze Estuary is a net source of nutrients and this can be interpreted to indicate that heterotrophic processes prevail. The differences in $\triangle D I P$ based on the derivation of $V_{X}$ are shown in Fig. $4 \mathrm{C}$. The positive $\Delta D I N$ indicates that Mhlathuze Estuary seems a source for DIN.
Due to extremely high flushing rate of the Mvoti and Thukela Estuaries, nutrient budgets probably cannot be considered reliable. However, assuming a steady state for both DIN and DIP over the sampling period, and that the nutrient contribution from groundwater is not known and nutrients in rainwater is considered to be negligible, the nutrient budget equation can be simplified to $\Delta Y=-V_{R} Y_{R}-V_{Q} Y_{O}-V_{\chi}\left(Y_{\text {ocean }}-Y_{\text {ou }}\right)$. The DIP and DIN concentrations used for calculating nutrient fluxes are shown in Tables 1 and 2 .

In the case of the Mvoti Estuary the non-conservative flux of DIP $(\triangle D I P)$ is $+634 \mathrm{~mol} \cdot \mathrm{d}^{-1}$ or $+3.4 \mathrm{mmol} \cdot \mathrm{m}^{-2} \cdot \mathrm{d}^{-1}$ is probably indicative of the removal of DIP from the system. Nonconservative DIN flux $(\triangle D I N)$ was positive $\left(+1544 \mathrm{~mol} \cdot \mathrm{d}^{-1}\right.$ or $\left.+8.4 \mathrm{mmol} \cdot \mathrm{m}^{-2} \cdot \mathrm{d}^{-1}\right)$ indicating that the estuary is acting as sink for non-conservative DIN (Figs. 5B and C). The source function of the estuary for both DIP and DIN from the system was expected since the input of primary treated sewage discharge into the Mvoti River is not reflected as concomitant increased DIP and DIN in the ocean adjacent to the estuarine mouth. The nutrient fluxes in the Thukela Estuary show a similar pattern and it should be borne in mind that nitrate in runoff is likely to be important since there are large sugar-cane fields on the banks of the lower reaches of the river and the estuary. The $\triangle D I P$ and $\triangle D I N$ are positive, indicating that the estuary is a net source of 

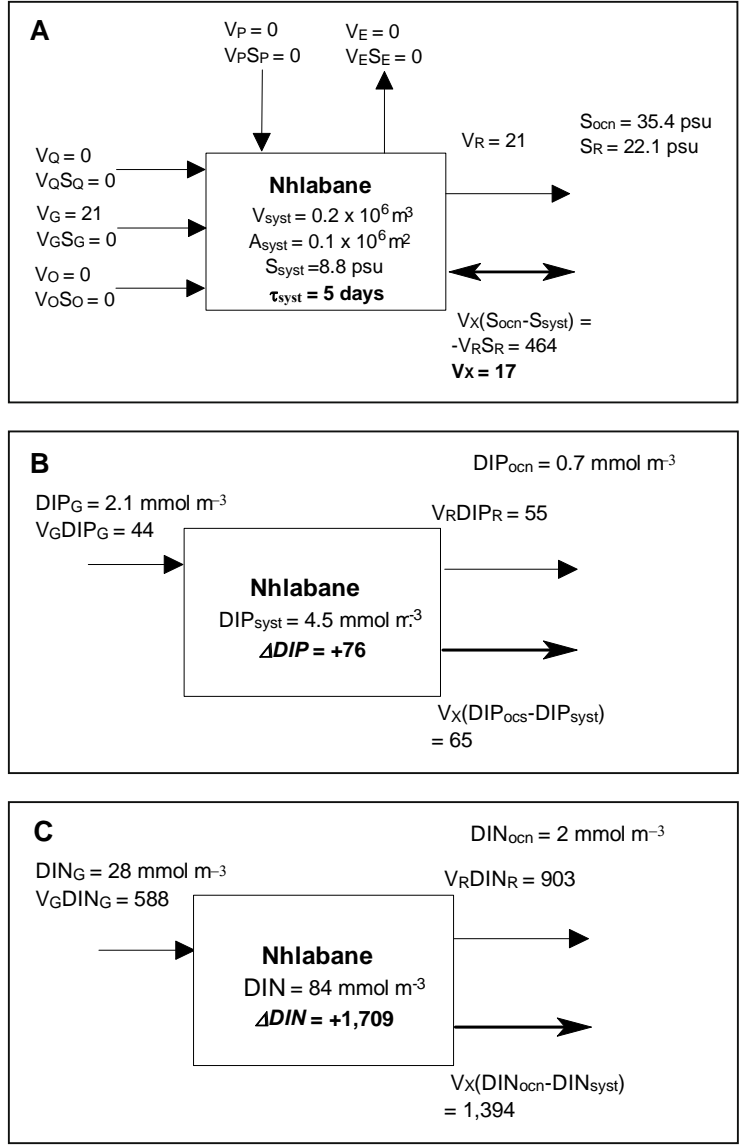

Figure 6

Water and salt budgets $(A)$, dissolved inorganic phosphorous budget $(B)$ and dissolved inorganic nitrogen budget $(C)$ for the Nhlabane Estuary. Water flux is presented in $10^{6} \cdot \mathrm{m}^{3} \cdot \mathrm{d}^{-1}$ and salt flux in $10^{6} \cdot \mathrm{psu}-\mathrm{m}^{3} \cdot \mathrm{d}^{-1}$, whereas nutrient fluxes are in $10^{3} \cdot \mathrm{m}^{3} \cdot \mathrm{d}^{-1}$.

nutrients (Figs. 7B and C). The flux of non-conservative DIP is $+15 \times 10^{3} \mathrm{~mol} \cdot \mathrm{d}^{-1}$ or $25 \mathrm{mmol} \cdot \mathrm{m}^{-2} \cdot \mathrm{d}^{-1}$; and non-conservative DIN is $+399 \times 10^{3} \mathrm{~mol} \cdot \mathrm{d}^{-1}$ or $665 \mathrm{mmol} \cdot \mathrm{m}^{-2} \cdot \mathrm{d}^{-1}$.

Estuarine systems with very short water exchange times often appear to behave as high sinks or sources of DIP and DIN e.g., Camboriu Estuary in Brazil (Dupra et al., 2000a). This apparent behaviour reflects the dominance of hydrographic processes, along with (small) uncertainties in the nutrient loads or concentrations. In fact, these systems should be considered to flush out all the nutrients as in the case of Mamberamo and Kuala Terrengganu Estuaries in the South-China Sea (Dupra et al., 2000b). This conclusion does not, in any sense, suggest that there is no non-conservative flux of nutrients in such systems; rather, the non-conservative flux is small relative to the conservative flux and cannot be resolved.

The $\triangle D I P$ and $\triangle D I N$ calculated for the Nhlabane Estuary are positive, indicating that the estuary is a net source of nutrients (Figs. 6B and C) The calculated flux of nonconservative DIP is $+76 \mathrm{~mol} \cdot \mathrm{d}^{-1}$ or $+0.8 \mathrm{mmol} \cdot \mathrm{m}^{-2} \cdot \mathrm{d}^{-1}$ and nonconservative DIN is $+1709 \mathrm{~mol} \cdot \mathrm{d}^{-1}$ or $+17 \mathrm{mmol} \cdot \mathrm{m}^{-2} \cdot \mathrm{d}^{-1}$. The system is a net source of DIP and DIN and indicates that heterotrophic processes prevail. It is possible that the groundwater input of DIN and DIP is an overestimation of input via this route since the data used were obtained from boreholes along the banks of Lake Nhlabane and not in the dunes surrounding the estuary.
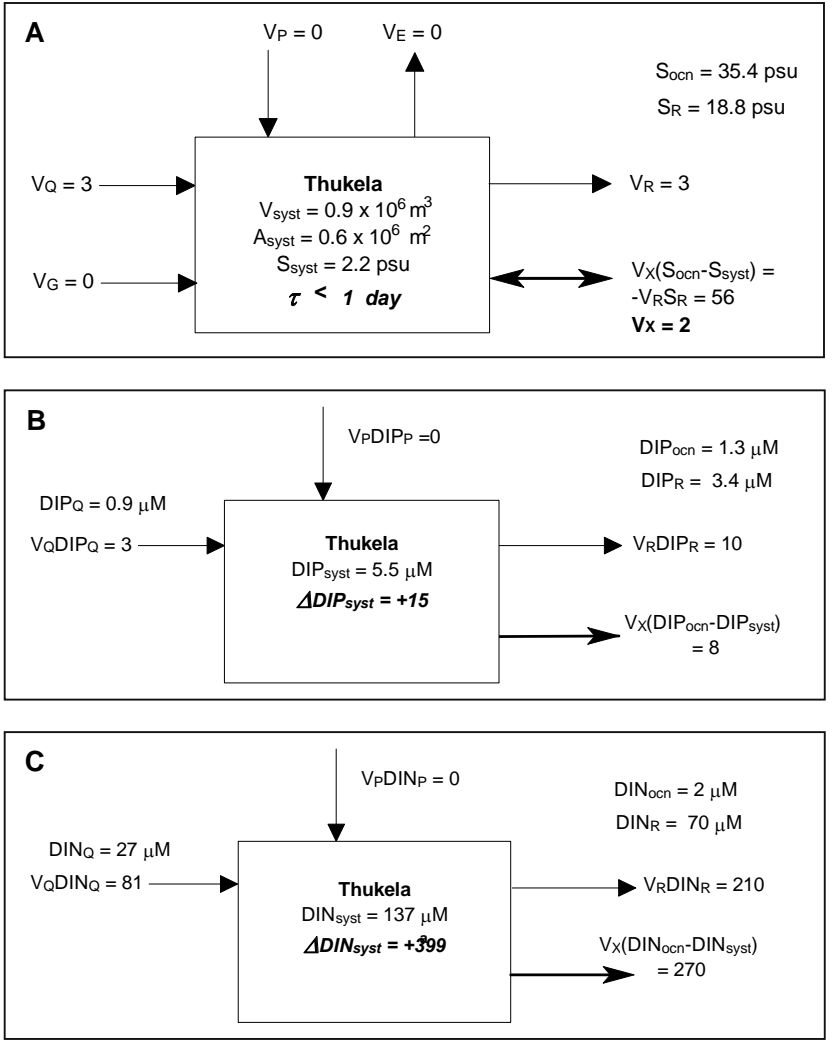

Figure 7

Water and salt budgets $(A)$, dissolved inorganic phosphorous budget $(B)$ and dissolved inorganic nitrogen budget (C) for the Thukela Estuary. Water flux is presented in $10^{6} \cdot \mathrm{m}^{3} \cdot \mathrm{d}^{-1}$ and salt flux in $10^{6} \cdot \mathrm{psu}-\mathrm{m}^{3} \cdot \mathrm{d}^{-1}$, whereas nutrient fluxes are in $10^{3} \cdot \mathrm{m}^{3} \cdot \mathrm{d}^{-1}$.

\section{Stoichiometric calculations of aspects of net system metabolism}

As was found with most of the permanently open river-driven estuarine systems in the LOICZ budget studies (Dupra et al., 2000b), it could be assumed that similar types of systems along the east coast of South Africa, that the rapid water exchange would result in a time constraint for biological processes to take place. Estimates of system metabolism in systems with rapid water exchange such as the Mhlathuze, Mvoti and Thukela Estuaries should therefore be viewed with caution. However, assuming that the Mhlathuze Estuary behaves more as having $V_{X}^{\mathrm{b}}$ and a longer water exchange time, net system metabolism was calculated. Since it is not completely obvious whether mangroves or phytoplankton are the dominating reactive organic matter, two N: P ratios are used. Assuming the bulk of the reacting organic matter is phytoplankton, the C: P ratio is $106: 1$, then for the Mhlathuze Estuary, net ecosystem metabolism: $(p-r)=-300$ $\mathrm{mmol} \cdot \mathrm{m}^{-2} \cdot \mathrm{d}^{-1}$. Assuming the bulk of the reacting organic matter is mangroves in the Mhlathuze, and at a C:P ratio of $1000: 1$ (Atkinson and Smith, 1983) the net ecosystem metabolism: ( $p-r)$ $=-3,000 \mathrm{mmol} \cdot \mathrm{m}^{-2} \cdot \mathrm{d}^{-1}$. Both $(p-r)$ values indicate that there is a net loss of organic matter from the Mhlathuze Estuary.

If the $\triangle D I P$ values in Mhlathuze Estuary are a measure of the net production of organic matter in the system, the expected $\Delta D I N\left(\Delta D I N_{e x p}\right)$ would be $\Delta D I P$ multiplied by the $\mathrm{N}$ : P ratio of the reacting organic matter. Large differences between $\triangle D I N_{\text {obs }}$ and $\Delta D I N_{\text {exp }}$ are indicators of processes other than organic metabolism, which alter fixed nitrogen such as the contribution 
of gaseous nitrogen. As nitrogen fixation and denitrification are important processes in coastal systems, the difference is taken as a measure of net nitrogen fixation minus denitrification. Again, because the major source of reacting matter is unclear, two N: $\mathrm{P}$ ratios are used. If phytoplankton is the principal form of organic matter in the Mhlathuze Estuary then, based on the Redfield Ratio $\Delta D I N_{\text {exp }}=16 \Delta D I P:[\text { fix } \text {-denit }]_{\text {phytoplankton }}=-40 \mathrm{mmol} \cdot \mathrm{m}$ ${ }^{2} \cdot \mathrm{d}^{-1}$. If the mangroves are the principal form of organic matter then, based on a median ratio for mangroves of C: N: P 1 000: 11: 1 (Atkinson and Smith, 1983), $\Delta D I N_{\text {exp }}=11 \Delta D I P$, so that: [ $n$ fixdenit $]_{\text {mangroves }}=-20 \mathrm{mmol} \cdot \mathrm{m}^{-2} \cdot \mathrm{d}^{-1}$. There is a strong likelihood that the mangroves do play the dominant role in contributing to the organic matter as unpublished results on nutrient fluxes from the Incomati Estuary in Mozambique clearly showed that mangroves were the main source of the exported organic material (Monteira, 2006). When considering that the mangroves in the Mhlathuze Estuary are extensive, this assumption is justified. The negative values indicate that denitrification processes are responsible for smaller $\Delta D I N_{\text {obs }}$ than $\triangle D I N_{\text {exp }}$

The net ecosystem metabolism of the Nhlabane Estuary [primary production-respiration $=(p-r)]$ was calculated as the negative of $\triangle D I P$ multiplied by the $\mathrm{C}: \mathrm{P}$ ratio of the reacting organic matter. It was not completely obvious whether the expansive reed beds ( $P$. australis) in the main channel of the estuary during the drought period or phytoplankton are the dominating reactive organic matter, so two N: $\mathrm{P}$ ratios are used. Assuming the bulk of the reacting organic matter is phytoplankton, at a $\mathrm{C}$ : $P$ ratio of 106:1, then the, net ecosystem metabolism $(p-r)=-84$ $\mathrm{mmol} \cdot \mathrm{m}^{-2} \cdot \mathrm{d}^{-1}$ for the Nhlabane Estuary. On the other hand, if we assume that the bulk of the reacting organic matter is reed beds with a C: P ratio of 300:1 (Smith, 2002), then the net ecosystem metabolism $(p-r)=-240 \mathrm{mmol} \cdot \mathrm{m}^{-2} \cdot \mathrm{d}^{-1}$.

The negative net ecosystem metabolism $(p-r)$ values indicate that the system is net heterotrophic with a net loss of organic matter from the Nhlabane Estuary. If the $\triangle D I P$ values in Nhlabane Estuary are a measure of the net production of organic matter in the system, the expected $\triangle D I N\left(\triangle D I N_{\text {exp }}\right)$ would be $\triangle D I P$ multiplied by the $\mathrm{N}: \mathrm{P}$ ratio of the reacting organic matter Large differences between $\Delta D I N_{o b s}$ and $\Delta D I N_{\text {exp }}$ are indicators of processes other than organic metabolism, which alter fixed nitrogen. As nitrogen fixation and denitrification are important processes in coastal systems, the difference is taken as a measure of net nitrogen fixation minus denitrification.

Again, because the major source of reacting matter is unclear, two N: P ratios are used. If phytoplankton is the principal form of organic matter in the Nhlabane Estuary then, based on the Redfield Ratio $\triangle D I N_{\text {exp }}=16 \Delta D I P:$ (nfix-denit) ${ }_{\text {phytoplankton }}=+4$ $\mathrm{mmol} \cdot \mathrm{m}^{-2} \cdot \mathrm{d}^{-1}$.If the Phragmites reedbeds are the principal form of organic matter then, based on a realistic ratio for these macrophytes of C: $\mathrm{N}: \mathrm{P} 300: 20: 1, \Delta D I N_{e x p}=20 \Delta D I P$, so that: (nfixdenit) ${ }_{\text {mangroves }}=+1 \mathrm{mmol} \cdot \mathrm{m}^{-2} \cdot \mathrm{d}^{-1}$. The positive values obtained indicate apparent slight net nitrogen fixation in the estuary.

\section{Interpretation of LOICZ budget results in terms of an eco-classification framework}

Since ecosystems are able to function at various levels of integrity, the EcoClassification process that is being implemented in freshwater systems, categorises the present ecological health or state in relation to what may be regarded as the natural or as close as possible to the natural reference condition (Kleynhans et al., 2005). The resulting classification procedure (which should not be confused with the Classification System as indicated in the National Water Act) allows for the recognition of a range of functioning conditions from a natural (pristine or unmodified conditions) to a poor state. A water quality reference condition is used to describe the natural unimpacted characteristics of a particular section of system (i.e. in a particular ecoregion prior to the influence of humans). Ideally, the reference condition should remain stable and not vary over time. However, due to seasonal variation it should be recognised that variations in the reference condition will occur. It is against this reference condition that changes within a system are benchmarked.

However, most water quantity and quality data for South African river systems only go back to the 1970 s and it is therefore extremely unlikely that data representing unimpacted conditions are available. The situation for estuaries is even worse. According to Whitfield (2000) the status of information on $68 \%$ of South Africa's estuaries is poor to nil. In many instances the data lacking most are on the physico-chemical properties of the water. With the limited data available, the LOICZ mass balance approach would therefore be an ideal model to assess nutrient fluxes in South African estuaries.

The results from the LOICZ modelling procedure represent steady state conditions for an estuary and as such it satisfies the data requirements for a reference condition, in the case of an unimpacted system or the present ecological status in a system that is impacted. The LOICZ model could therefore provide a reference (or best attainable) condition for nutrient fluxes in a particular estuary. Any changes, be it changes in freshwater inflow, nutrient input, salinity change, etc. will be reflected as deviations from the reference or benchmark fluxes. Since the changes in fluxes would affect the estuarine functioning, it would inevitably also affect the general integrity of the estuary. The degree to which the values deviate from the reference condition can be an indication of the change in the integrity of the system, which in turn may be represented as an altered assessment category.

No reference conditions can be specified without data being available. In the event of no water quality data being available for an estuary, it would be essential that a monitoring program be designed and implemented to generate data for use in the model. It is recommended that a MINIMUM of weekly sampling is carried out over a $60 \mathrm{~d}$ period (DWAF, 1999). The data required and potential sources of these data are presented in Table 3. Once the data have been sourced and/or collected (following a monitoring programme) the nutrient fluxes can be calculated using the LOICZ modelling approach.

Potential changes in fluxes can be evaluated once a reference condition or present ecological status condition has been calculated. Table 4 presents the proposed categories with corresponding conditions for changes in nutrient fluxes. There is at present no scientific basis for the selection of the allowable deviation within each assessment class. The allowable deviations were selected based on the category delimitation used for total dissolved solids in freshwater environments (DWAF, 1999). The validity and applicability of these deviations can only be assessed once this procedure is tested in real-time applications.

To demonstrate the application of the technique described above, the data from the Mhlathuze Estuary (Table 1) were used as an example. The fluxes calculated in Fig. 4 were taken as the reference condition for the estuary and the hypothetical effect of a $20 \%$ reduction in riverine runoff was assessed on the water, salt and nutrient budgets. In this example the nutrient concentrations from all the sources (river, system and ocean) remained constant. A further hypothetical $100 \%$ increase in riverine input of DIN, without any changes in volume, was also assessed. These results are presented in Table 5 . It must be 


\begin{tabular}{|c|c|}
\hline \multicolumn{2}{|c|}{$\begin{array}{c}\text { TABLE } 3 \\
\begin{array}{c}\text { Data requirements and potential sources of data for calculating water, salinity and nutrient fluxes using the } \\
\text { LOICZ mass balance model }\end{array}\end{array}$} \\
\hline Quantity & Data source \\
\hline $\begin{array}{l}\text { System catchment } \\
\text { area }\left(\mathrm{m}^{2}\right)\end{array}$ & Available literature (Colloty, 2000) or computed using Cabaret software \\
\hline System volume $\left(\mathrm{m}^{3}\right)$ & Available data or computed using Cabaret software \\
\hline $\mathrm{V}_{\mathrm{Q}}\left(10^{3} \cdot \mathrm{m}^{3} \cdot \mathrm{d}^{-1}\right)$ & $\begin{array}{l}\text { Average flow as measured at the most downstream DWAF weir for the particular river (DWAF Hydrologi- } \\
\text { cal database) }\end{array}$ \\
\hline $\mathrm{V}_{\mathrm{P}}\left(10^{3} \cdot \mathrm{m}^{3} \cdot \mathrm{d}^{-1}\right)$ & $\begin{array}{l}\text { Average yearly rainfall from the South African Weather Bureau as supplied by the Computing Center for } \\
\text { Water Research (CCWR) for the particular river catchment. }\end{array}$ \\
\hline $\mathrm{V}_{\mathrm{E}}\left(10^{3} \cdot \mathrm{m}^{3} \cdot \mathrm{d}^{-1}\right)$ & $\begin{array}{l}\text { Average yearly evaporation rates from the South African Weather Bureau as supplied by the Computing } \\
\text { Center for Water Research (CCWR) for the particular catchment. }\end{array}$ \\
\hline $\mathrm{V}_{\mathrm{G}}\left(10^{3} \cdot \mathrm{m}^{3} \cdot \mathrm{d}^{-1}\right)$ & Ground water recharge calculated for a particular geographical region (WR90 hydrological data base) \\
\hline $\mathrm{S}_{\text {ocn }}(\%)$ & Average measured marine salinity. \\
\hline $\mathrm{S}_{\text {syst }}(\%)$ & Average salinity measured in the estuary. \\
\hline $\mathrm{DIP}_{\mathrm{Q}}, \mathrm{DIN}_{\mathrm{Q}}(\mathrm{mM})$ & $\begin{array}{l}\text { Averaged nutrients recorded by DWAF in the lower reaches of a particular rivers system (DWAF water } \\
\text { quality database) or average measured nutrients. }\end{array}$ \\
\hline $\mathrm{DIP}_{\text {syst }}, \mathrm{DIN}_{\mathrm{syst}}(\mathrm{mM})$ & $\begin{array}{l}\text { Available data or in the case of no available data the weekly averages of nutrients recorded for at least } \\
\text { eight consecutive weeks from a site in the particular estuary. }\end{array}$ \\
\hline DIP $_{\text {ocn }}, \mathrm{DIN}_{\mathrm{ocn}}(\mathrm{mM})$ & Available data or use the Levitus 94 dataset of the Lanman-Doherty Environmental Observatory. \\
\hline
\end{tabular}

borne in mind that this is a very crude example with only one input parameter changing. In a real-time situation the altered freshwater inflow would have an effect on the salinity of the system, the salt budget, mixing flux and nutrient loads into the system. These changes can only be quantified with actual measurements of these parameters. The calculated flux values, based on the changed volume and concentration data are related to the 'Reference condition' in terms of a percentage deviation from the benchmark using the classification system given in Table 5 . It becomes evident that changes in flow result in drastic changes in both the mixing flux $(\Delta 21.8 \%)$ and the $\Delta D I N(\Delta 24 \%)$. This would place the Estuary in a Fair category with respect to mixing and nutrient fluxes. In contrast the doubling of the DIN from freshwater input only changes the DIN flux by $7.4 \%$, resulting in the estuary remaining in the Natural category. It must once again be emphasised that in this example only one parameter was changed and the fluxes would be considerably different if all the other LOICZ modelling parameters were measured. However, this example does show that it is possible to use this relatively simple budget model to set reference flux conditions and then assess any deviation from a hypothetical benchmark in terms of an estuarine water quality assessment category. The ensuing results would point out areas where management actions can be targeted, which may include reduction of point-source nutrient loads into the system or rehabilitation of riparian zones to decrease the nutrient runoff from agricultural areas.

\section{Acknowledgements}

Funding for this research was made possible by the Water Research Commission (WRC) through Project No. K1163. A special word of thanks is also expressed to the LOICZ team of Steve Smith and Chris Crossland for the stimulating discussions that resulted in the formulation of this paper.

\section{References}

ALLANSON BR (2001) Some factors governing the water quality of micro-tidal estuaries in South Africa. Water SA 27 (3) 373-386.

\begin{tabular}{|c|c|}
\hline \multicolumn{2}{|c|}{$\begin{array}{c}\text { TABLE 4 } \\
\text { Assessment categories for the nutrient status } \\
\text { based on deviations of fluxes from the reference } \\
\text { condition }\end{array}$} \\
\hline $\begin{array}{l}\text { Nutrient } \\
\text { assessment } \\
\text { category }\end{array}$ & $\begin{array}{l}\text { The median flux (water, salinity, DIN, DIP) } \\
\text { should not differ from the Reference } \\
\text { Condition by greater than: }\end{array}$ \\
\hline Natural & $15 \%$ \\
\hline Good & $20 \%$ \\
\hline Fair & $30 \%$ \\
\hline Poor & $>40 \%$ \\
\hline
\end{tabular}

\begin{tabular}{|c|c|c|c|}
\hline \multicolumn{4}{|c|}{$\begin{array}{c}\text { TABLE } 5 \\
\text { The effect of changed water volumes and nutrient } \\
\text { concentrations on the water, salt and nutrient } \\
\text { budgets of the Mhlathuze Estuary. } \\
\text { Reference condition is represented by RC }\end{array}$} \\
\hline \multirow[t]{2}{*}{ Variable } & Value & $\begin{array}{l}\text { New flux } \\
\text { values }\end{array}$ & $\begin{array}{l}\text { New flux } \\
\text { values }\end{array}$ \\
\hline & RC & $\begin{array}{c}20 \% \text { lower } \\
\text { flow }\end{array}$ & $\begin{array}{c}\text { Increased } \\
\text { DIN }\end{array}$ \\
\hline $\mathrm{V}_{\mathrm{Q}}\left(10^{3} \cdot \mathrm{m}^{3} \cdot \mathrm{d}^{-1}\right)$ & 438 & 350 & 438 \\
\hline $\mathrm{V}_{\mathrm{P}}\left(10^{3} \cdot \mathrm{m}^{3} \cdot \mathrm{d}^{-1}\right)$ & 39 & 39 & 39 \\
\hline$V_{E}\left(10^{3} \cdot m^{3} \cdot d^{-1}\right)$ & -42 & -42 & -42 \\
\hline $\mathrm{V}_{\mathrm{G}}\left(10^{3} \cdot \mathrm{m}^{3} \cdot \mathrm{d}^{-1}\right)$ & 12 & 12 & 12 \\
\hline $\mathrm{S}_{\mathrm{ocn}}(\mathrm{psu})$ & 35.4 & 35.4 & 35.4 \\
\hline $\mathrm{S}_{\text {syst }}(\mathrm{psu})$ & 34.5 & 34.5 & 34.5 \\
\hline $\mathrm{DIP}_{\mathrm{Q}}, \mathrm{DIN}_{\mathrm{Q}}(\mu \mathrm{M})$ & $0.7,25$ & $0.7,25$ & $0.7,50$ \\
\hline $\mathrm{DIP}_{\mathrm{G}}, \mathrm{DIN}_{\mathrm{G}}(\mu \mathrm{M})$ & $1.0,14$ & $1.0,14$ & $1.0,14$ \\
\hline $\mathrm{DIP}_{\text {syst }}, \mathrm{DIN}_{\text {syst }}(\mu \mathrm{M})$ & $5.8,14$ & $5.8,14$ & $5.8,14$ \\
\hline $\mathrm{DIP}_{\text {ocn }}, \mathrm{DIN}_{\mathrm{ocn}}(\mu \mathrm{M})$ & $0.1,0.7$ & $0.1,0.7$ & $0.1,0.7$ \\
\hline $\mathrm{V}_{\mathrm{x}}\left(10^{6} \mathrm{psu}-\mathrm{m}^{3} \cdot \mathrm{d}^{-1}\right)$ & 17359 & 13572 & 17359 \\
\hline$\Delta \mathrm{DIP}\left(10^{3} \mathrm{M} \cdot \mathrm{m}^{3} \cdot \mathrm{d}^{-1}\right)$ & 100 & 100 & 100 \\
\hline$\Delta \operatorname{DIN}\left(10^{3} \mathrm{M} \cdot \mathrm{m}^{3} \cdot \mathrm{d}^{-1}\right)$ & 223 & 168.8 & 206 \\
\hline
\end{tabular}


ALLANSON BR and WINTER PED (1999) Chemistry. In: Allanson BR and Baird D (eds.) Estuaries of South Africa. Cambridge Univ. Press. 53-90.

ANZECC (2000) Australian and New Zealand Guidelines for Fresh and Marine Water Quality. Vol. 1: The Guidelines. Paper 4. Australia and New Zealand Environment and Conservation Council and Agriculture and Resource Management Council of Australia and New Zealand, Canberra, Australia.

ARCHIBALD CGM (1998a) Estuarine Flow Requirements of the Thukela River: Water Quality Issues. CSIR Report ECP-6000/6E03/ JEA12/020. Durban, South Africa.

ARCHIBALD CGM (1998b) Protection of Lake Mzingazi from Pollution. Status Report for 1997/1998. CSIR, Durban.

ATKINSON MJ and SMITH SV (1983) C: N: P ratios of benthic marine plants. Limnol. Oceanogr. 28 568-574.

BEGG GW (1984) The Estuaries of Natal, Part II. Natal Town and Regional Planning Report No. 55, Pietermaritzburg.

BEGG GW (1978) The Estuaries of Natal. Natal Town and Regional Planning Report No. 14. Pietermaritzburg, South Africa.

CLEAN STREAM (2000) Iscor Heavy Minerals Project: KwaZuluNatal. Integrated Biological, Water quality, Water quantity and Statistical Evaluation Report: Second Quarter 2000. Clean Stream Environmental Services, Pretoria, South Africa.

COOKS J and BEWSHER P (1993) Environmental reaction to human intervention in the Mhlathuze River Estuary, Richards Bay, South Africa. Geoökodynamik 14 61-74.

CYRUS DP, WEPENER V, MACKAY CF, VOS PM, VILJOEN A and WEERTS SP (2000) Effects of Inter-Basin Water Transfer on the Hydrochemistry, Benthic Invertebrates and Ichthyofauna of the Mhlathuze Estuary and Lake Nseze. WRC Report No. K2/720. Water Research Commission, Pretoria, South Africa.

DAVIES BR and SNADDON K (2000) Ecological Effects of Interbasin Water Transfer Schemes in Dryland Environments. WRC Report No. K5/665. Water Research Commission, Pretoria, Pretoria, South Africa.

DODD N (1994) On the destabilization of a longshore current of a plane beach: bottom shear stress, critical conditions, and onset of instability. J. Geophys. Res. 99 (C1) 811-824

DUPRA V, SMITH SV, DAVIDS LT, WALDRON H, MARSHALL CROSSLAND JI and CROSSLAND CJ (2002) Estuarine Systems of Africa (Regional Workshop II): Carbon, Nitrogen and Phosphorus Fluxes. LOICZ Reports and Studies 20, LOICZ, Texel. The Netherlands. $81 \mathrm{pp}$.

DUPRA V, SMITH SV, MARSHALL CROSSLAND, JI and CROSSLAND CJ (2000a) Estuarine Systems of the South American Region: Carbon, Nitrogen and Phosphorus Fluxes. LOICZ Reports and Studies 15, LOICZ, Texel, The Netherlands. $87 \mathrm{pp}$.

DUPRA V, SMITH SV, MARSHALL CROSSLAND, JI and CROSSLAND CJ (2000b) Estuarine Systems of the South China Sea Region: Carbon, Nitrogen and Phosphorus Fluxes. LOICZ Reports and Studies 14, LOICZ, Texel, The Netherlands. $156 \mathrm{pp}$.

DWAF (Department of Water Affairs and Forestry) (1999) Methodology for Preliminary Determination of the Ecological Reserve. Institute for Water Quality Studies, Pretoria.

EKHOLM P, MALVE O and KIRKKALA T (1997) Internal and external loading as regulators of nutrient concentrations in the agriculturally loaded Lake Pyhajarvi. Hydrobiol. 345 (1) 3- 14.

ERFTEMEIJER PLA and MIDDLEBURG JJ (1995) Mass balance constraints on nutrient cycling in tropical seagrass beds. Aquat. Bot. 50 21-36.

GORDON JR, DC, BOUDREAU PR, MANN KH, ONG J-E, SILVERT WL, SMITH SV, WATTAYAKORN G, WULFF F and YANAGI $\mathrm{T}$ (1996) LOICZ Biogeochemical Modelling Guidelines. LOICZ Reports and Studies No 5. 1-96.
GROBBELAAR J U (1992) Nutrients versus physical factors determining primary productivity of waters with high inorganic turbidity. Hydrobiol. 238 177-182.

HARRISON TD, COOPER JAG and RAMM AEL (2000) Geomorphology, Ichthyofauna, Water Quality and Aesthetics of South African Estuaries. Report No. ENV-DC 2000-01. Department of Environmental Affairs and Tourism, Pretoria, South Africa.

KEMPER N (1999) Nhlabane Lake Water Level Requirements: An Initial Assessment. Mhlathuze Ecological Reserve Study, IWR Environmental.

KLEYNHANS CJ, LOUW MD, THIRION C, ROSSOUW NJ and ROWNTREE K (2005) River EcoClassification: Manual for EcoStatus Determination (Version 1). Joint Water Research Commission and Department of Water Affairs and Forestry report. WRC Report No. KV 168/05. Water Research Commission, Pretoria, South Africa.

LOUW D (1998) Mhlathuze Ecological (Quantity) Reserve Study IFR. Unpublished Starter Document for IFR Specialist Meeting held in Mtunzini, KwaZulu-Natal, South Africa, 26-30 October 1998.

MACKAY CF, WEERTS SP and CYRUS DP (2000) High and Low Flow Survey of the Lower Mvoti River and Estuary: Preliminary Results of High Flow Survey. CRUZ Investigational Report No. 88: $1-21$.

MONTEIRA PMS (2006) Perspectives on the Catchment to Coast programme, its Outputs and Possible Outcomes. Presentation at the Annual Conference of the Southern African Society of Aquatic Scientists, 19-22 June 2006, Maputo, Mozambique.

MVOTI IFR STARTER DOCUMENT (1996) Unpublished Report for Instream Flow Requirements Workshop of the Mvoti River, Department of Water Affairs and Forestry, Pretoria, South Africa.

PERNETTA JC and MILLIMAN JD (1995) Land Ocean Interactions in the Coastal Zone: Implementation Plan. ICGP Change Report No. 33. International Geosphere Biosphere Programme, Stockholm. 215 pp.

QUINN N (1999) Nhlabane Estuarine Flow Requirements: An Initial Assessment. Mhlathuze Ecological Reserve Study, IWR Environmental.

REDFIELD AC (1934) On the proportions of organic derivatives in sea water and their relation to the composition of plankton. James Johnstone Memorial Volume 177-192.

SMITH S (2002) Estuarine systems of Africa (Regional Workshop II): Carbon, nitrogen and phosphorus fluxes. LOICZ Workshop, September. Simonstown, South Africa.

TALJAARD S and SLINGER J (1997) Decision Support Requirements for Estuarine Water Quality Management. CSIR Technical Report, ENV/S - T97001. CSIR, Stellenbosch.

VIVIER L, CYRUS DP, JERLING HL and CILLIERS GJ (1998) Effect of the Dredger Crossing on the Nhlabane Estuary - Final Report. CRUZ Investigational Report No. 57: 1-69.

WEPENER V and VERMEULEN LA (1999) Comments on the water quality of the Mhlathuze Estuary in relation to determining the ecological integrity class. S. Afr. J. Aquat. Sci. 24 (1/2) 18-27.

WHITFIELD AK (1992) A characterisation of southern African estuarine systems. S. Afr. J. Aquat. Sci. 18 (1/2) 89-103.

WHITFIELD AK (2000) Available Scientific Information on Individual South African Estuarine Systems. WRC Report No. 577/3/00. Water Research Commission, Pretoria, South Africa. 217 pp.

YANAGI T (2000a) Coastal Oceanography. Kluwer Publishers, Dortrecht, $162 \mathrm{pp}$

YANAGI T (2000b) Simple Method for Estimating $\mathrm{V}_{\mathrm{x}}$ from Mixing Equations in a 1-Dimensional, Steady-State System for LOICZ Biogeochemical Modeling. Unpublished LOICZ document. 3 pp. 